\title{
In vitro Studies on Efficacy of Agro-Chemicals against Collar Rot of Tomato Caused by Sclerotium rolfsii Saccin Manipur, India
}

\author{
K. Dinesh ${ }^{1}$, Bireswar Sinha ${ }^{1 *}$, Ph. Sobita Devi ${ }^{1}$, Rahee Bui ${ }^{1}$, \\ Roseline Salam ${ }^{1}$ and AjitKumar Savani ${ }^{2}$ \\ ${ }^{1}$ Department of Plant Pathology, College of agriculture, \\ Central Agricultural University, Imphal, India \\ ${ }^{2}$ Department of Plant Pathology, Assam Agricultural University, Jorhat-785013 \\ *Corresponding author
}

\section{A B S T R A C T}

\begin{tabular}{|l|}
\hline Ke y w or d s \\
$\begin{array}{l}\text { Fungicide, Insecticide, } \\
\text { Herbicide }\end{array}$ \\
\hline Article Info \\
\hline $\begin{array}{l}\text { Accepted: } \\
18 \text { April } 2018 \\
\text { Available Online: } \\
10 \text { May } 2018\end{array}$ \\
\hline
\end{tabular}

\section{Introduction}

Sclerotium rolfsii is a soil inhabitant, nontarget, polyphagous, and a ubiquitous facultative parasite. It is widely distributed in the world and has host range of 500 plant species. It was first observed by Peter Henry Rolfs in the year 1892 on tomato plants with $70 \%$ losses. The hyphae grew upward on the surface of the infected plant covered with a cottony, white mass of mycelium, scattered inside and outside of infected stem nearby the soil surface. Its major survival mechanism is through sclerotial bodies which can persist in temperature range of $-10{ }^{0} \mathrm{C}$ to $50{ }^{\circ} \mathrm{C}$ (kator et al., 2015). Its geographic distribution, profuse mycelial growth, persistent sclerotia and large number of hosts attacked by it indicate that, economic losses are substantial every year due to infection of S. rolfsii. Keeping in view the significance of economic crops, the present findings were carried out to understand the effect of various agro-chemicals against S. rolfsii.

\section{Materials and Methods}

\section{Survey and isolation of fungusfrom diseased samples}

Tomato plant showed collar rot symptoms were collected from the surveyed areas and brought to laboratory for isolation. Fungus was isolated from diseased samples on PDA medium. The fungus was identified based on the morphological descriptions of Narain and 
Mishra (1977) as S. rolfsii. The culture was maintained in PDA slants by sub culturing time to time and stored in refrigerator $\left(4^{\circ} \mathrm{C}\right)$ for further studies. Among the isolates the one with highest virulence was taken for management studies.

\section{Pathogenicity test}

Sterilized soil was taken in earthen pots of size $45 \times 30 \mathrm{~cm}^{2}$. Thirty days old culture of $S$. rolfsii grown on the sorghum grains was mixed thoroughly with soil. Healthy tomato seedlings were transplanted in the sick soil. Healthy plants transplanted in pots without inoculum served as check. Moisture was maintained at 25 per cent moisture holding capacity of soil by adding water on weight basis throughout the period. Re-isolation was made from such affected portion of the plant tissue and compared with the original culture.

\section{Poisoned food technique}

In vitro efficacy of some agro-chemicals like fungicides (Difenconazole, Propiconazole, Hexaconazole), herbicides (Pendimethalin, Paraquat, Glyphosate) and insecticides (Imidachloprid, Fipronil, Chlorpyriphos) each with three different concentrations were studied against $s$. rolfsii. Required quantity of chemical was added into sterilized molten and cooled potato dextrose agar to get the desired concentrations. Mycelial discs of $5 \mathrm{~mm}$ size of five day old culture of the fungus were cut by using sterile cork borer and one such disc was placed at the centre of each agar plate and control treatment was maintained without adding any chemical to the medium.

Then such plates were incubated in BOD at temperature $25 \pm 1^{\circ} \mathrm{C}$ for six days and radial growth was measured. The per cent inhibition of mycelial growth over control which was calculated by using the formula given by Vincent (1927) given below:
Percent inhibition $=(\mathrm{C}-\mathrm{T}) / \mathrm{C} \times 100$

Where $\mathrm{C}=$ linear growth of the fungus in control, $\mathrm{T}=$ linear growth of the fungus in treatment

\section{Results and Discussion}

\section{In vitro efficacy fungicides on growth of $S$. rolfsii}

Among the fungicides studied hexaconazole had showed best result, with 100 percent inhibition at lowest concentration (12.5ppm), whereas propiconazole had showed 100, 80.8, $77.13 \%$ inhibition at 50, 25 and $12.5 \mathrm{ppm}$ respectively. Difenconazole had showed $82.17,69.19$ and 27.92 at 50, 25 and $12.5 \mathrm{ppm}$ respectively (Table 1, Graph 1, Plate 1). Findings are in accordance with Chowdhury et.al. 1998 who reported that hexaconazloe even at low concentration (50ppm) is superior in inhibiting the growth of $S$. rolfsii. Triazoles are potent inhibitors of ergosterol synthesis, the major membrane sterol of fungi. They block the cytochrome P450-dependent enzyme C-14 alpha-demethylase, which is needed to convert lanosterol to ergosterol and thus maysupressed the growth of S. rolfsii.

\section{In vitro efficacy herbicides on growth of $S$. rolfsii}

Among the herbicides pendimethalin had showed best result at lowest concentration $(0.2 \%)$. Hundred percent inhibition of the fungus was observed by Pendimethalin 0.2, 0.4 and $0.8 \%$, Glyphosate at 1 and $2 \%$ and paraquat at $1 \%$. $64.53 \%$ inhibition was observed for glyphosate $0.5 \% .45 .15$ and 81.78 percent inhibition was observed in paraquat 2.5 and $5 \%$ respectively(Table 2, Graph 2, Plate 2). These results are in accordance with pastor and March, 1998 who confirmed the effectiveness of pendimethalin against $S$. rolfsii. 
Table.1 In vitro efficacy fungicides on growth of S. rolfsii

\begin{tabular}{|c|c|c|c|}
\hline Treatments & Fungicide & Concentration(ppm) & Inhibition (\%) \\
\hline T1 & Difenoconazole & 12.5 & $27.91 *(5.28)^{* *}$ \\
\hline T2 & & 25 & $69.19(8.40)$ \\
\hline T3 & & 50 & $82.17(9.03)$ \\
\hline T4 & Hexaconazole & 12.5 & $100.00(10.02)$ \\
\hline T5 & & 25 & $100.00(10.02)$ \\
\hline T6 & & 50 & $100.00(10.02)$ \\
\hline T7 & Propiconazole & 12.5 & $77.13(8.80)$ \\
\hline T8 & & 25 & $80.81(9.01)$ \\
\hline T9 & & 50 & $100.00(10.02)$ \\
\hline
\end{tabular}

Table.2 In vitro efficacy of herbicides on growth of S. rolfsii

\begin{tabular}{|c|c|c|c|}
\hline Treatments & Herbicide & Concentration (\%) & Inhibition (\%) \\
\hline T1 & Paraquat & $0.25 \%$ & $45.15^{*}(6.76)^{* *}$ \\
\hline T2 & & $0.5 \%$ & $81.78(9.06)$ \\
\hline T3 & & $1.0 \%$ & $100(10.02)$ \\
\hline T4 & Glyphosate & $0.5 \%$ & $64.73(8.08)$ \\
\hline T5 & & $1 \%$ & $100(10.02)$ \\
\hline T6 & & $2 \%$ & $100(10.02)$ \\
\hline T7 & Pendimethalin & $0.2 \%$ & $88.26(9.39)$ \\
\hline T8 & & $0.4 \%$ & $100(10.02)$ \\
\hline T9 & & $0.8 \%$ & $100(10.02)$ \\
\hline & SE(d) \pm & & 0.033 \\
\hline
\end{tabular}

Table.3 In vitro efficacy of insecticides on growth of S.rolfsii

\begin{tabular}{|r|c|c|c|}
\hline Treatments & Insecticide & Concentration (\%) & Inhibition (\%) \\
\hline T1 & Imidacloprid & $0.03 \%$ & $6.10^{*}(0.85)^{* *}$ \\
\hline T2 & & $0.06 \%$ & $42.63(1.63)$ \\
\hline T3 & & $0.12 \%$ & $47.67(1.68)$ \\
\hline T4 & Fipronil & $0.125 \%$ & $50.19(1.70)$ \\
\hline T5 & & $0.25 \%$ & $54.46(1.74)$ \\
\hline T6 & & $0.50 \%$ & $64.34(1.82)$ \\
\hline T7 & Chlorpyriphos & $0.125 \%$ & $100(2.00)$ \\
\hline T8 & & $0.25 \%$ & $100(2.00)$ \\
\hline T9 & & $0.50 \%$ & $100(2.00)$ \\
\hline
\end{tabular}


Graph.1 In vitro efficacy of fungicides on growth of $S$. rolfsii In vitro efficacy fungicides on growth of S. rolfsii

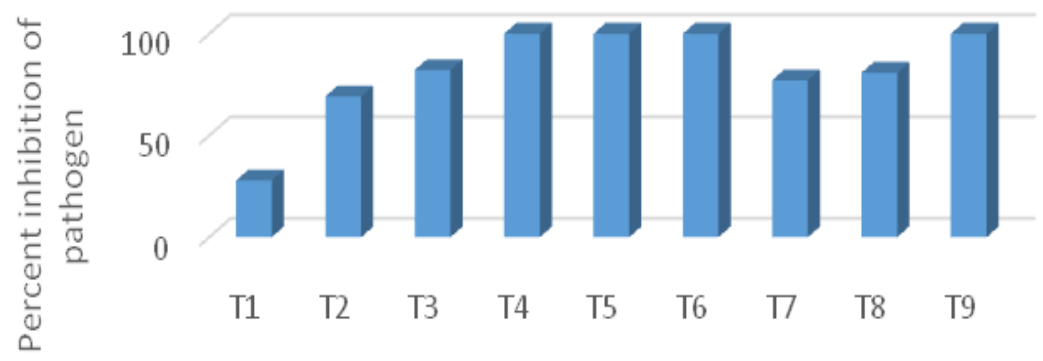

Treatments

Graph.2 In vitro efficacy of herbicides on growth of $S$. rolfsii

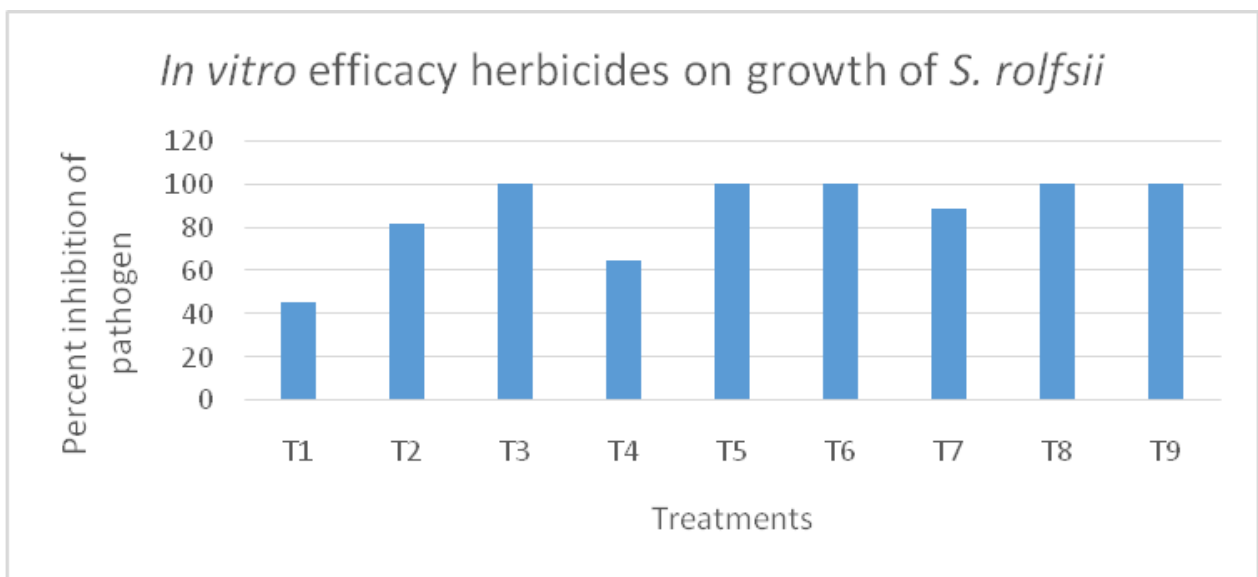

Graph.3 In vitro efficacy of insecticides on growth of $S$. rolfsii

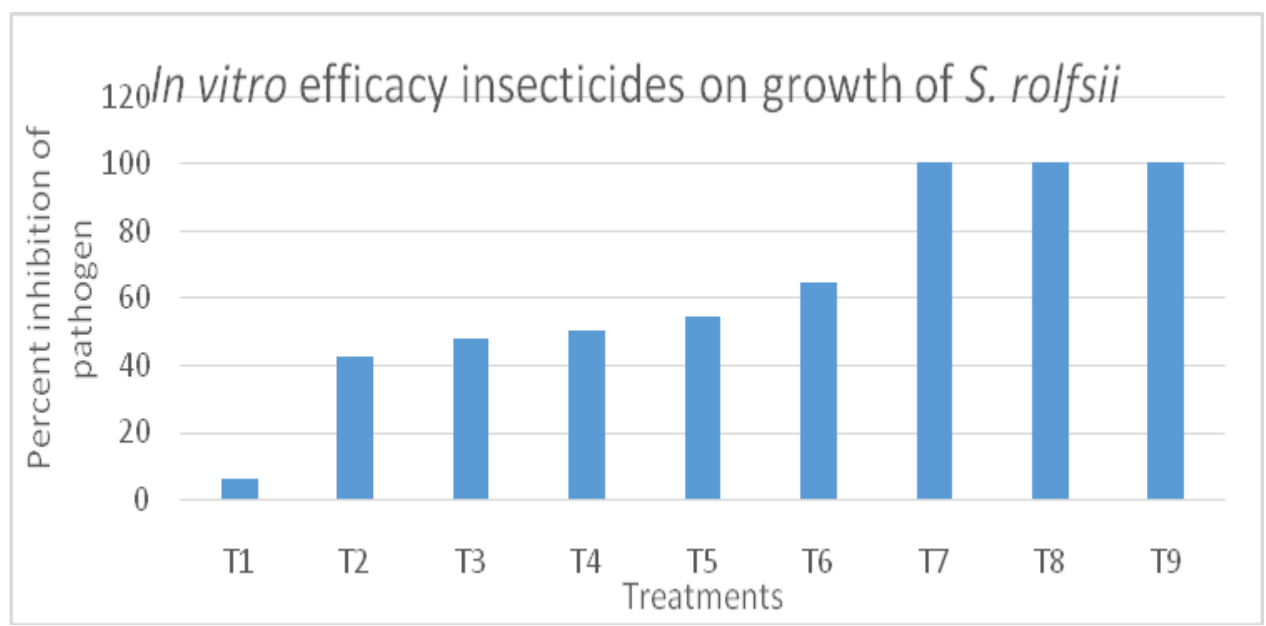


Plate.1 In vitro efficacy of fungicides on the growth of S. rolfsii

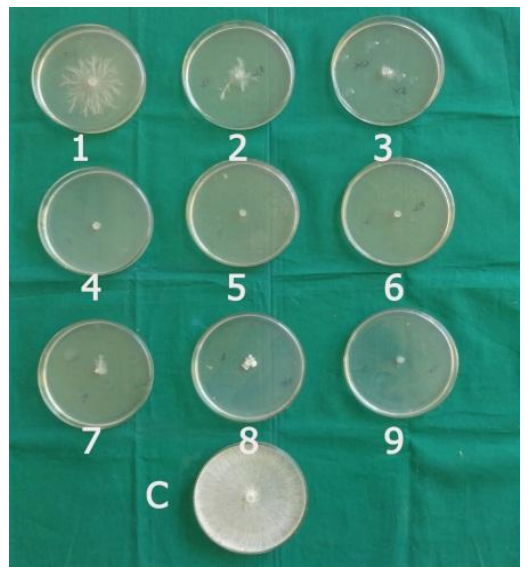

C. Control, 1. Difenoconazole (12.5ppm), 2. Difenoconazole (25ppm), 3. Difenoconazole (50ppm) 4. Hexaconazole (12.5ppm), 5. Hexaconazole (25ppm), 6. Hexaconazole (50ppm), 7. Propiconazole (12.5 ppm), 8. Propiconazole (25 ppm), 9. Propiconazole (50 ppm),

Plate.2 In vitro efficacy of herbicides on growth of S. rolfsii

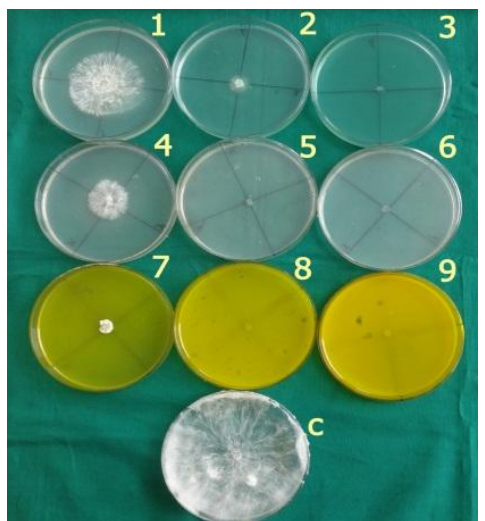

C. Control, 1. Paraquat $(0.25 \%)$, 2. Paraquat $(0.5 \%)$, 3. Paraquat (1\%), 4. Glyphosate $(0.5 \%), 5$. Glyphosate (1 $\%), 6$. Glyphosate $(2 \%), 7$. Pendimethalin $(0.2 \%), 8$. Pendimethalin $(0.4 \%), 9$. Pendimethalin $(0.8 \%)$.

Plate.3 In vitro efficacy of insecticides on the growth of $S$. rolfsii

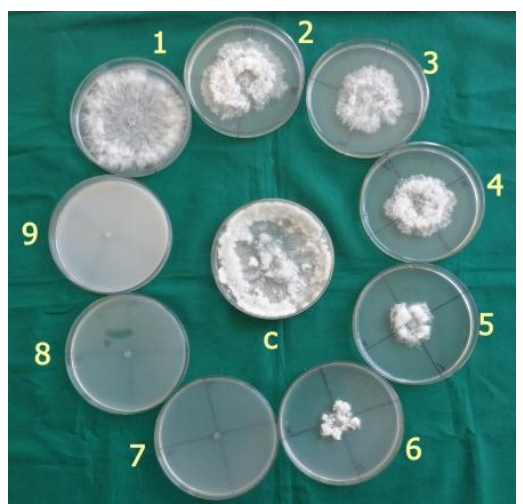

C. Control, 1. Imidacloprid (0.03\%), 2. Imidacloprid (0.06\%), 3. Imidacloprid (0.12\%), 4. Fipronil (0.125\%), 5. Fipronil (0.25\%), 6.Fipronil (0.5\%), 7.Chlorpyriphos (0.125\%), 8.Chlorpyriphos $(0.25 \%)$, 9. Chlorpyriphos $(0.5 \%)$. 
Effect of non-target pesticides on growth of $S$. rolfsii was confirmed by Awasti and Dasgupta (2011) and Pastor and March, 1999.Glyphosate is a broad-spectrum herbicide and potent inhibitor of 5-enolpyruvyl shikamate 3-phosphate synthase (EPSPS), a key enzyme in the synthesis of aromatic amino acids present in plants, fungi and bacteria. Consequently, fungi and bacteria with glyphosate-sensitive EPSPS may be susceptible to the action of glyphosate. Similarly other herbicides may have non target effects on pathogen leads to supression of growth of pathogen.

\section{In vitro efficacy insecticides on growth of $S$. rolfsii}

Among the insecticides Chlorpyriphos had shown best results at its lowest concentration $(0.125 \%)$. Chlorpyriphos had showed cent percent inhibition at three of its concentrations used i.e.0.125, 0.25 and $0.5 \%$, whereas Fipronil had showed 50.19, 54.46 and 64.34 percent inhibition at concentrations $0.125,0.25$ and $2.5 \%$ respectively. Imidachloprid had showed least inhibition of 6.10 percent at the concentration of $0.03 \%$, followed by 42.63 and 47.67 percent inhibition at concentrations of 0.06 and $0.12 \%$ respectively (Table 3, Graph 3, Plate 3). These results are in accordance with Singh et.al. 2007 their findings revealed that non- target pesticides monocrotphos, 2, 4.D and nuvan completely inhibited the growth of S.rolfsii. The effectiveness of chlorpyriphos may be due to its hydrolysis break down product 3, 5, 6-trichloro-2-pyridinol which has substantial effect on growth of $S$. rolfsii.

Triazole group of fungicides had shown considerable effect on growth of Sclerotium rolfsii. The present findings showed herbicides and insecticides had positive impact on reducing the growth of S. rolfsii. Therefore it may be concluded that some agro-chemicals may have positive impact for reduction of $S$. rolfsii inoculum in field condition.

\section{References}

Awasthi, D.P. and Dasgupta, B. 2011. Studies on bio-efficacy of herbicides against Sclerotium rolfsii Sacc. Causing stem rot of groundnut Arachis hypogaea L. under in vitro condition. Journal of Mycopathological Research, 492: 365-366.

Chowdhury, K.A., Reddy, D.R. and Rao, K.C. 1998. Efficiency of systemic triozoles and non-systemic fungicides against Sclerotium wilt of bell pepper caused by Sclerotium rolfsiiSacc. Indian J. Plant Protection, 26:125-130.

Kator, L., Hosea, Z. and Oche, O. 2015.Sclerotium rolfsii; causative organism of southern blight, stem rot, white mold and sclerotia rot disease. Annals of Biological Research, 611: 78-89.

Pastor, S. and March, G.J. 1999. Effect of in vitro of residual herbicide used in peanut on Sclerotium rolfsii. Fitopathologia, 34: 116$121 .$.

Rolfs, P.H. 1892. Tomato blight: some hints. Bulletin Fla. Agric. Experimentation Station, p.18.

Singh, S.R., Prajapati, R.R., Srivastava, S.S.L., Pandey, R.R. and Gupta, P.R. 2007. Evaluation of different botanicals and nontarget pesticides against Sclerotium rolfsii causing collar rot of Lentil. Indian Phytopath., 60: 499- 501.

Vincent J.M. 1927. Distortion of fungal hyphae in presence of certain inhibitors, Nature, 159:850.

\section{How to cite this article:}

Dinesh K., Bireswar Sinha, Ph. Sobita Devi, Rahee Bui, Roseline Salam and AjitKumar Savani. 2018. In vitro Studies on Efficacy of Agro-Chemicals against Collar Rot of Tomato Caused by Sclerotium rolfsii Saccin Manipur, India. Int.J.Curr.Microbiol.App.Sci. 7(05): 2503-2508.

doi: https://doi.org/10.20546/ijcmas.2018.705.288 